\title{
Determination of Vitamin B12 Using Differential Pulse Polarography
}

\author{
Şükrü Kalayci*, Ülkü Ünal, Güler Somer \\ Chemistry Department, Gazi University, Ankara, Turkey \\ Email: *skalayci@gazi.edu.tr
}

How to cite this paper: Kalayci, S., Ünal, Ü. and Somer, G. (2020) Determination of Vitamin B12 Using Differential Pulse Polarography. American Journal of Analytical Chemistry, 11, 187-196. https://doi.org/10.4236/ajac.2020.115014

Received: April 5, 2020

Accepted: April 24, 2020

Published: April 27, 2020

Copyright (๑) 2020 by author(s) and Scientific Research Publishing Inc. This work is licensed under the Creative Commons Attribution International License (CC BY 4.0).

http://creativecommons.org/licenses/by/4.0/ (c) (i) Open Access

\begin{abstract}
Vitamin B12 is a type of vitamin also known by the name cobalamin. B12 is involved in many metabolism activities, including DNA synthesis, nervous system, red blood formation and immune system. Therefore, we chose the Differential Pulse Polarography (DPP) method is that has a high sensitivity for the determination of vitamin B12. This determination was possible with cobalt present in vitamin B12 structure. Since $\mathrm{Co}(\mathrm{III})$ is formed from the oxidation of the vitamin, its polarographic behavior had to be determined in various electrolytes such as acetate, borate, phosphate and ammonia. The polarograms of $\mathrm{Co}$ (III) were taken in these electrolytes in which $1.0 \mathrm{M} \mathrm{NH}_{3} / \mathrm{NH}_{4}^{+}$ $(\mathrm{pH}=9.8)$ and $1.0 \mathrm{M} \mathrm{AcOH} / \mathrm{AcO}^{-}(\mathrm{pH}=4.0)$ were found as the most suitable electrolytes. This method was successfully applied vitamin of B12 determination in a $1 \mathrm{~mL}$ ampoule with high precision. The LOD was found as $3.7 \times 10^{-7}$ for instead of $(\mathrm{S} / \mathrm{N}=3)$. Besides $\mathrm{Co}(\mathrm{III})$, interference effects of $\mathrm{Zn}(\mathrm{II}), \mathrm{Ni}(\mathrm{II})$, $\mathrm{Cr}(\mathrm{III}), \mathrm{Fe}(\mathrm{III}), \mathrm{Cu}(\mathrm{II}), \mathrm{Cd}(\mathrm{II})$ and $\mathrm{Se}(\mathrm{IV})$ were also studied. It was found that only $\mathrm{Zn}$ (II) peak had an overlap Co(III) peak in ammonium buffer. This problem could be solved by working in $1.0 \mathrm{M} \mathrm{AcOH} / \mathrm{AcO}^{-}(\mathrm{pH}=4.0)$ buffer. $\mathrm{B} 12$, which is $1000 \mu \mathrm{g}$ in $1 \mathrm{~mL}$ vitamin ampoule, was found for 4 measurements as $999 \pm 15 \mu \mathrm{g}$ as a result of $95 \%$ confidence interval.
\end{abstract}

\section{Keywords}

Vitamin B12, Determination, Cobalt, Differential Pulse Polarography, Interferences Studies

\section{Introduction}

Vitamin B12 is a type of vitamin also known as cobalamin, and it is a water-soluble vitamin like other B vitamins. He is involved in many metabolism ac- 
tivities, especially DNA synthesis, nervous system, it formation and immune system. Its chemical structure is quite complex. There is a very rare biochemical cobalt mineral in the central region, and this cobalamin is named after this mineral. B12 is made using the cobalt analysis. Electrochemical methods are preferred because of their high sensitivity and low interference effect in the determination of cobalt.

Differential pulse polarography has some advantages. It is a method that does not require enrichment and extraction in DPP for the determination of trace amounts of elements. These kinds of determinations are rarely possible in many analytical methods [1] [2]. Some interference studies can easily be done with DP polarography; the reproducibility is very high when compared with different methods [3] [4] [5]. Same cations with several oxidation numbers can easily be determined with DPP. Determination of Sn(II) with Sn(IV) and determination of $\mathrm{As}(\mathrm{III})$ with $\mathrm{As}(\mathrm{V})$ can give for such examples [6] [7]. Some molecules such as ascorbic acid [8], vitamin K3 [9], uric acid [10] and nitrite [11] which are not so easy to determine with the above given methods, can also be determined with our DP polarographic methods without any difficulty.

B12 in vitamin B12 tablets were determined by detection by a high performance liquid chromatography [12]. Vitamin B12, both in foods and in premixes, was determined by reversed-phase liquid chromatography with UV detection [13]. A new method was reported for the direct determination of B12 in seawater based on $\mathrm{C} 18$ solid-phase extraction and quantification by Reversed-Phase High-Performance Liquid Chromatography (HPLC) with an UV-V is detector [14].

UV-visible spectrophotometric, adsorptive stripping voltammetry and capillary electrophoretic study of metal ions have been studied and application was made to the determination of Co(III) in vitamin B12 [15]. The semi-derivate voltammetric peak current method was applied to determine the content of vitamin B12 in pharmaceutical preparations using gold modified electrode [16]. Cyclic voltammetry $(\mathrm{CV})$ and square wave adsorptive stripping voltammetry (SWAdSV) were used to investigate the performance of an ex situ plated bismuth-film electrode (BiFE) employed to study the electrochemical behavior and the electroanalytical determination of vitamin B12 [17]. Trace Cobalt in vitamin B12 is determined by polarography using a complex of $\mathrm{Co}$ (II)-thymolphthaleinnitrite. With this adsorptive wave it was possible to determine cobalt in vitamin B12 [18]. A Self-Catalytic Carbon Paste Electrode for the detection of vitamin $\mathrm{B} 12$ has been constructed and it was used for the quantification of vitamin B12 in pharmaceutical products and biological matrix media [19].

In this study, vitamin B12 was determined with the cobalt contained in it. In the analysis, high sensitivity differential pulse polarography was used. In this analysis, the interference effects of other cations were examined. The appropriate medium for vitamin B12 determination was investigated and the vitamin B12 in the ampoule was analyzed in this medium. 


\section{Experimental}

\subsection{Apparatus}

A PAR (Model 174A) polarographic analyzer system equipped with a PAR mercury drop timer was used. The natural drop time of the mercury electrode was in the range of $2-3 \mathrm{~s}(2.37 \mathrm{mg} / \mathrm{s})$. A Kalousek electrolytic cell with a reference saturated calomel electrode (SCE), separated by a liquid junction, was used in the 3 -electrode configuration, so that the IR drop can be eliminated. The counter electrode was platinum wire. The polarograms were recorded with a Linseis (LY1600) X-Y recorder. DP polarograms were recorded under the conditions of a drop life of $1 \mathrm{~s}$, a scan rate of $5 \mathrm{mV} / \mathrm{s}$, and a pulse amplitude of $50 \mathrm{mV}$.

\subsection{Reagents}

Various supporting electrolytes including ammonium, acetate, borate and phosphate buffer with or without EDTA were used over a wide $\mathrm{pH}$ range.

1.0 M AcOH/AcONa electrolyte: It was prepared by adding $6 \mathrm{~g}$ of solid $\mathrm{NaOH}$, washed with distilled water in order to remove the carbon-ate formed, into 57 $\mathrm{mL}$ of $1.0 \mathrm{M} \mathrm{AcOH}$, and diluting into $1 \mathrm{~L}$ with distilled water. The $\mathrm{pH}$ was adjusted with the addition of acid or base to the de-sired value using a $\mathrm{pH}$ meter.

$1.0 \mathrm{M}$ Borate buffer: $12.4 \mathrm{~g} \mathrm{H}_{3} \mathrm{BO}_{3}$ was dissolved in small amount of distilled water in a $100 \mathrm{~mL}$ volumetric flask, then $4.0 \mathrm{~g} \mathrm{NaOH}$ was added and all of them was dissolved with distilled water. The $\mathrm{pH}$ was adjusted by the addition of an appropriate amount of $1.0 \mathrm{M} \mathrm{NaOH}$ to the desired value using a $\mathrm{pH}$ meter.

$1.0 \mathrm{M} \mathrm{NH}_{3} / \mathrm{NH}_{4} \mathrm{Cl}$ buffer: $8 \mathrm{~mL}$ of concentrated $\mathrm{NH}_{3}$ is added into a $100 \mathrm{~mL}$ volumetric flask, after addition of $5.0 \mathrm{~g}$ of $\mathrm{NH}_{4} \mathrm{Cl}$ and about $100 \mathrm{~mL}$ distilled water, the $\mathrm{pH}$ was adjusted to 9.8 , by the addition of $1.0 \mathrm{M} \mathrm{NaOH}$ using a $\mathrm{pH}$ meter.

1.0 M Phosphate buffer: $15.6 \mathrm{~g}$ of $\mathrm{Na} \mathrm{H}_{2} \mathrm{PO}_{4} \cdot 2 \mathrm{H}_{2} \mathrm{O}$ and $7.8 \mathrm{~g}$ of $\mathrm{Na}_{2} \mathrm{HPO}_{4} \cdot 2 \mathrm{H}_{2} \mathrm{O}$ are dissolved in water and diluted into $100 \mathrm{~mL}$ in a volumetric flask. Then $50 \mathrm{~mL}$ is taken from this solution and its $\mathrm{pH}$ was adjusted by the addition of $1 \mathrm{M} \mathrm{NaOH}$ to the required $\mathrm{pH}$ value using a $\mathrm{pH}$ meter.

$0.1 \mathrm{M} \mathrm{Mo}$ (VI) solution: $0.88 \mathrm{~g}$ of $\left(\mathrm{NH}_{4}\right)_{6} \mathrm{Mo}_{7} \mathrm{O}_{24} \cdot 4 \mathrm{H}_{2} \mathrm{O}$ is dissolved in distilled water and diluted into $50 \mathrm{~mL}$.

$0.1 \mathrm{M} \mathrm{Se}(\mathrm{IV})$ solution: $0.28 \mathrm{~g}$ of $\mathrm{SeO}_{2}$ is dissolved in hot distilled water and diluted into $50 \mathrm{~mL}$.

Standard 0.1 M Co(II), $\mathrm{Pb}(\mathrm{II}), \mathrm{Zn}(\mathrm{II}), \mathrm{Ni}(\mathrm{II})$, and $\mathrm{Cu}(\mathrm{II})$ solutions were prepared from their standard nitrate solutions. However, $\mathrm{Fe}(\mathrm{III}), \mathrm{Cr}(\mathrm{III})$ and $\mathrm{Cd}(\mathrm{II})$ solutions, their chloride salt was used.

Preparation of B12 vitamin solution: Since Cobalt is present in the organic structure of vitamin B12, it had to be decomposed with concentrated acid mixture as given below, so that the organic structure was decomposed and $\mathrm{Co}$ (III) ions could be dissolved in the solution. Thus, it was possible to determine vitamin B12 from the dissolved $\mathrm{Co}(\mathrm{III})$. For the destruction of B12 molecule, so that $\mathrm{Co}$ (III) can be determined, $0.5 \mathrm{~mL} \mathrm{H}_{2} \mathrm{SO}_{4}$ and $5 \mathrm{~mL} \mathrm{HNO}_{3}$ was added to $1 \mathrm{~mL}$ of 
B12 vitamin taken from the ampoule. It was left wait until the solution was clear. Then it was warmed up while shaking the solution, until the solution left was about $0.5 \mathrm{~mL}$. When it was cool the final solution was made $1 \mathrm{~mL}$ using distilled water. By the addition of these acids, the organic structure will decompose and $\mathrm{Co}(\mathrm{III})$ ions will become free.

\section{Results and Discussion}

\subsection{Determination of the Optimum Working Conditions for Co(III)}

Since cobalt ion is present in vitamin B12 as Co(III) after destruction with acids, the best medium for its determination had to be studied. For this purpose in various electrolytes such as $\mathrm{pH}=2,4$ and $5 \mathrm{AcOH}$ electrolyte, borate, phosphate and $\mathrm{NH}_{3} / \mathrm{NH}_{4} \mathrm{Cl}$ buffer the DP polarograms were taken and the peak potentials and peak heights for $1 \times 10^{-5} \mathrm{M}$ Co(III) were determined (Table 1 ). As can be seen from Table 1 the most suitable electrolytes for the determination of $\mathrm{Co}$ (III) was found as $1.0 \mathrm{M} \mathrm{NH}_{3} / \mathrm{NH}_{4} \mathrm{Cl}(\mathrm{pH}=9.8)$ and $1.0 \mathrm{M} \mathrm{AcOH} / \mathrm{AcO}^{-}(\mathrm{pH}=4.0)$ because of their peak heights. However, only in $1.0 \mathrm{M} \mathrm{NH}_{3} / \mathrm{NH}_{4} \mathrm{Cl}(\mathrm{pH}=9.8)$ electrolyte the peak of $\mathrm{Co}$ (III) was high and sharp. In $1.0 \mathrm{M} \mathrm{AcOH} / \mathrm{AcO}^{-}(\mathrm{pH}=$ 4.0) electrolyte on the other hand the peak was high enough but it was not as sharp as it was in ammonia. Figure 1 is given as an example for the determination of Cobalt.

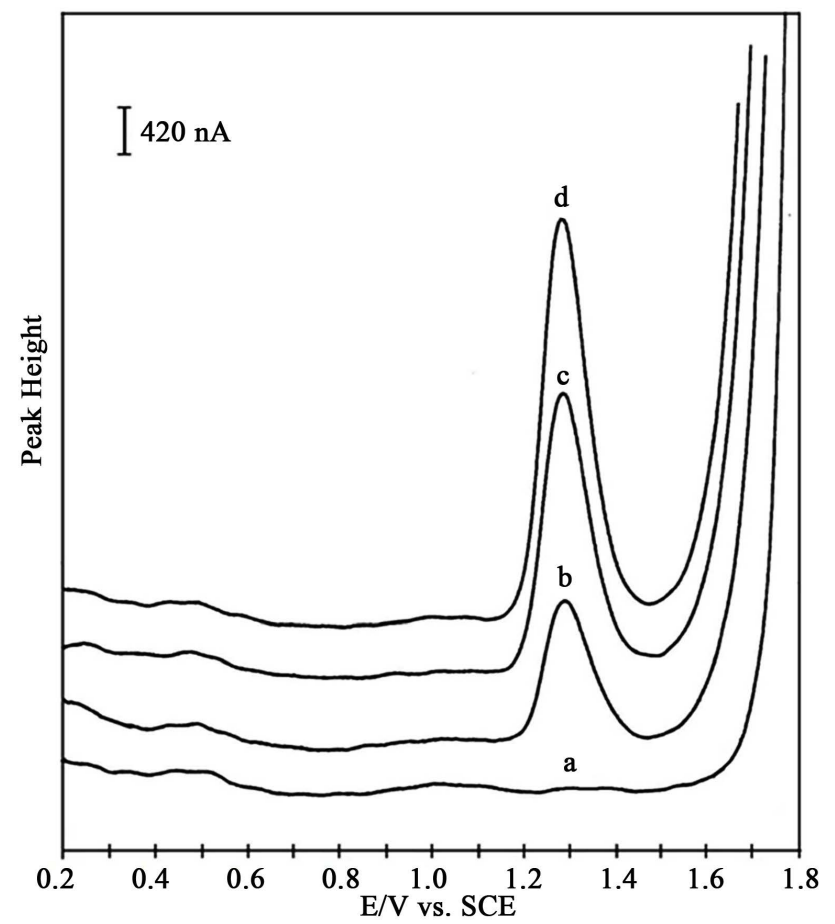

Figure 1. Determination of $1 \times 10^{-5} \mathrm{M} \mathrm{Co}$ (III) with standard additions ((b), (c), (d)) in $1.0 \mathrm{M} \mathrm{NH}_{3} / \mathrm{NH}_{4} \mathrm{Cl}$ buffer $(\mathrm{pH}=9.8)$. a: $10 \mathrm{~mL} 1.0 \mathrm{M} \mathrm{NH}_{3} / \mathrm{NH}_{4} \mathrm{Cl}$ buffer $(\mathrm{pH}=9.8)$; b: $\mathrm{a}+$ $0.1 \mathrm{~mL} 1 \times 10^{-3} \mathrm{M} \mathrm{Co}(\mathrm{III}) ; \mathrm{c}: \mathrm{b}+0.1 \mathrm{~mL} 1 \times 10^{-3} \mathrm{M} \mathrm{Co}(\mathrm{III}) ; \mathrm{d}: \mathrm{c}+0.1 \mathrm{~mL} 1 \times 10^{-3} \mathrm{M}$ Co(III). 
Table 1 . The peak potentials and shapes of $1 \times 10^{-5} \mathrm{M} \mathrm{Co}$ (III) in various buffers.

\begin{tabular}{ccccc}
\hline Medium & Ion & $\begin{array}{c}\text { Peak potential } \\
(\mathrm{V})\end{array}$ & $\begin{array}{c}\text { Peak height } \\
(\mathrm{mm})\end{array}$ & $\begin{array}{c}\text { Peak } \\
\text { shape }\end{array}$ \\
\hline $1.0 \mathrm{M}$ Borate buffer $(\mathrm{pH}=9.5)$ & $1 \times 10^{-5} \mathrm{M} \mathrm{Co}^{3+}$ & -1.43 & $11 \pm 1$ & Broad \\
$1.0 \mathrm{M} \mathrm{Phosphate} \mathrm{buffer}(\mathrm{pH}=9.6)$ & $1 \times 10^{-5} \mathrm{M} \mathrm{Co}^{3+}$ & -1.64 & $11 \pm 1$ & Broad \\
$1.0 \mathrm{M} \mathrm{HAc} \mathrm{Ac}^{-}$buffer $(\mathrm{pH}=4.0)$ & $1 \times 10^{-5} \mathrm{M} \mathrm{Co}^{3+}$ & -1.35 & $33 \pm 1$ & Broad \\
$1.0 \mathrm{M} \mathrm{NH}_{3} / \mathrm{NH}_{4} \mathrm{Cl}$ buffer $(\mathrm{pH}=9.8)$ & $1 \times 10^{-5} \mathrm{M} \mathrm{Co}^{3+}$ & -1.28 & $32 \pm 1$ & Sharp \\
\hline
\end{tabular}

\subsection{Interference Studies}

There is no element other than Co(III) in the composition of vitamin B12 in ampoule. However, some elements may be added for some purposes. In this case, there may appear some interference.

The most common ions Fe(III), $\mathrm{Zn}$ (II), Ni(II), Cu(II), Cr(VI), Se(IV), Cd(II) and $\mathrm{Pb}(\mathrm{II})$, were investigated for their possible interference effect. The peak potentials of the above given ions are studied in two different electrolytes, $1.0 \mathrm{M}$ $\mathrm{NH}_{3} / \mathrm{NH}_{4} \mathrm{Cl}(\mathrm{pH}=9.8)$ and $\mathrm{AcOH} / \mathrm{AcO}^{-}(\mathrm{pH}=4.0)$, since these were the best electrolytes for $\mathrm{Co}$ (III) determinations.

Their peak potentials are summarized in Table 2. As can be seen there will be no peak overlap with any ion except with $\mathrm{Zn}$ (II) in $1.0 \mathrm{M} \mathrm{NH}_{3} / \mathrm{NH}_{4} \mathrm{Cl}(\mathrm{pH}=$ 9.8). In this medium while $\mathrm{Co}(\mathrm{III})$ peak was at $-1.28 \mathrm{~V}, \mathrm{Zn}$ peak was at $-1.32 \mathrm{~V}$ and both were sharp. That is, in the presence of $\mathrm{Zn}(\mathrm{II})$, the determination of $\mathrm{Co}$ (III) will not be correct in $1.0 \mathrm{M} \mathrm{NH}_{3} / \mathrm{NH}_{4} \mathrm{Cl}(\mathrm{pH}=9.8)$.

In AcOH electrolyte $(\mathrm{pH}=4.0)$ on the other hand, Table 3, there is no peak overlap between $\mathrm{Zn}$ and $\mathrm{Co}(\mathrm{III})$. However, while Zn peak was sharp, Co(III) peak was broad and thus, the accuracy for $\mathrm{Co}(\mathrm{III})$ determination cannot be high. Because of the low accuracy for $\mathrm{Co}(\mathrm{III})$ in $\mathrm{AcOH}$ electrolyte $(\mathrm{pH}=4.0)$ medium, in our further studies we preferred to use $\mathrm{NH}_{3}$ buffer for the determination of $\mathrm{Co}(\mathrm{III})$. However, in the presence of $\mathrm{Zn}(\mathrm{II})$ ion, $\mathrm{Co}(\mathrm{III})$ can be determined in $\mathrm{AcOH}(\mathrm{pH}=4.0)$ medium but with low accuracy (Table 3).

\subsection{Determination of Co(III) in Artificially Prepared Solution Containing Fe(III) Using $1.0 \mathrm{M} \mathrm{NH}_{3} / \mathrm{NH}_{4} \mathrm{Cl}(\mathrm{pH}=9.8)$ Electrolyte}

For this purpose a $10 \mathrm{~mL}$ artificially prepared solution is prepared containing 1 $\times 10^{-3} \mathrm{M} \mathrm{Co}(\mathrm{III})$ and $1 \times 10^{-3} \mathrm{M} \mathrm{Fe}(\mathrm{III})$ (this maybe the most possible ion added to the vitamin ) from this solution $0.1 \mathrm{~mL}$ is taken and added into a polarographic cell containing $10 \mathrm{Ml} \mathrm{NH} / \mathrm{NH}_{4} \mathrm{Cl}(\mathrm{pH}=9.8)$ electrolyte. The polarogram obtained was as same as which was obtained for pure $\mathrm{Co}(\mathrm{III})$ solution. While no peak for $\mathrm{Fe}(\mathrm{III})$ was observed, a peak for $\mathrm{Co}(\mathrm{III})$ at $-1.28 \mathrm{~V}$ was observed. Its quantity could be calculated by standard additions of $10^{-5} \mathrm{M} \mathrm{Co}$ (III) solution. The quantity of $1 \times 10^{-5} \mathrm{M} \mathrm{Co}(\mathrm{III})$ was found with only $1.6 \%$ error and the results found are given in Table 4. The LOD was found as $3.7 \times 10^{-7} \mathrm{M}$ with $\mathrm{S} / \mathrm{N}=3$. 
Table 2. The peak potentials and shapes of $\mathrm{Co}(\mathrm{III}), \mathrm{Zn}(\mathrm{II}), \mathrm{Ni}(\mathrm{II}), \mathrm{Cr}(\mathrm{VI}), \mathrm{Fe}(\mathrm{III}), \mathrm{Cu}(\mathrm{II})$, $\mathrm{Cd}(\mathrm{II})$ and $\mathrm{Se}(\mathrm{IV})$ in $\mathrm{NH}_{3} / \mathrm{NH}_{4}$ buffer at $\mathrm{pH}=9$.

\begin{tabular}{ccccc}
\hline Medium & Ions & $\begin{array}{c}\text { Peak potantial } \\
(\mathrm{V})\end{array}$ & $\begin{array}{c}\text { Peak height } \\
(\mathrm{mm})\end{array}$ & $\begin{array}{c}\text { Peak } \\
\text { shape }\end{array}$ \\
\hline & $1 \times 10^{-5} \mathrm{M} \mathrm{Co}(\mathrm{III})$ & -1.28 & $32 \pm 1$ & Sharp \\
& $1 \times 10^{-5} \mathrm{M} \mathrm{Zn}(\mathrm{II})$ & -1.32 & $30 \pm 1$ & Sharp \\
& $1 \times 10^{-5} \mathrm{M} \mathrm{Ni}(\mathrm{II})$ & -1.09 & $22 \pm 1$ & Sharp \\
$1.0 \mathrm{M} \mathrm{NH}_{3} / \mathrm{NH}_{4} \mathrm{Cl}$ buffer & $1 \times 10^{-5} \mathrm{M} \mathrm{Cr}(\mathrm{VI})$ & -0.28 & $45 \pm 1$ & Sharp \\
$(\mathrm{pH}=9.8)$ & $1 \times 10^{-5} \mathrm{M} \mathrm{Fe}(\mathrm{III})$ & No peak & No peak & No peak \\
& $1 \times 10^{-5} \mathrm{M} \mathrm{Cu}(\mathrm{II})$ & -0.47 & $17 \pm 1$ & Sharp \\
& $1 \times 10^{-5} \mathrm{M} \mathrm{Cd}(\mathrm{II})$ & -0.78 & $53 \pm 1$ & Sharp \\
& $1 \times 10^{-5} \mathrm{M} \mathrm{Se}(\mathrm{IV})$ & -1.60 & $35 \pm 1$ & Broad \\
\hline
\end{tabular}

Table 3. The polarographic behavior of $1 \times 10^{-5} \mathrm{M} \mathrm{Co}(\mathrm{III}), \mathrm{Zn}$ (II) and $\mathrm{Fe}(\mathrm{III})$ ions in 1.0 $\mathrm{M} \mathrm{AcOH} / \mathrm{AcO}^{-}$electrolyte under various $\mathrm{pH}$ values.

\begin{tabular}{ccccc}
\hline $\begin{array}{c}\text { Medium 1.0 M } \\
\mathrm{AcOH} \mathrm{AcO}^{-}\end{array}$ & Ions & $\begin{array}{c}\text { Peak potantial } \\
(\mathrm{V})\end{array}$ & $\begin{array}{c}\text { Peak height } \\
(\mathrm{mm})\end{array}$ & Peak Shape \\
\hline $\mathrm{pH}=2$ & $1 \times 10^{-5} \mathrm{M} \mathrm{Co}(\mathrm{III})$ & No peak & No peak & No peak \\
$\mathrm{pH}=2$ & $1 \times 10^{-5} \mathrm{M} \mathrm{Zn(II)}$ & -1.02 & $11 \pm 1$ & Broad \\
$\mathrm{pH}=2$ & $1 \times 10^{-5} \mathrm{M} \mathrm{Fe}(\mathrm{III})$ & No peak & No peak & No peak \\
$\mathrm{pH}=4$ & $1 \times 10^{-5} \mathrm{M} \mathrm{Co}(\mathrm{III})$ & -1.35 & $33 \pm 1$ & Broad \\
$\mathrm{pH}=4$ & $1 \times 10^{-5} \mathrm{M} \mathrm{Zn}(\mathrm{II})$ & -1.02 & $35 \pm 1$ & Sharp \\
$\mathrm{pH}=4$ & $1 \times 10^{-5} \mathrm{M} \mathrm{Fe}(\mathrm{II})$ & No peak & No peak & No peak \\
$\mathrm{pH}=5$ & $1 \times 10^{-5} \mathrm{M} \mathrm{Co}(\mathrm{III})$ & -1.43 & $11 \pm 1$ & Broad \\
$\mathrm{pH}=5$ & $1 \times 10^{-5} \mathrm{M} \mathrm{Zn}(\mathrm{II})$ & -1.09 & $20 \pm 1$ & Broad \\
$\mathrm{pH}=5$ & $1 \times 10^{-5} \mathrm{M} \mathrm{Fe}(\mathrm{III})$ & No peak & No peak & No peak \\
\hline
\end{tabular}

Table 4. Determination of $\mathrm{Co}(\mathrm{III})$ in a synthetic sample contaninig $1 \times 10^{-5} \mathrm{M}$ (Fe(III), $\mathrm{Co}(\mathrm{III}))$ in $1.0 \mathrm{M} \mathrm{NH}_{3} / \mathrm{NH}_{4} \mathrm{Cl} \mathrm{pH}=9.8$ buffer.

\begin{tabular}{cccccc}
\hline Medium & $\begin{array}{c}{\left[\mathrm{Co}^{3+}\right](\mathrm{M}) \text { in }} \\
\text { synthetic sample }\end{array}$ & $\begin{array}{c}\text { Determined } \\
{\left[\mathrm{Co}^{3+}\right](\mathrm{M})}\end{array}$ & $\overline{\boldsymbol{x}}$ & $\boldsymbol{s}$ & $\overline{\boldsymbol{x}} \pm \mathbf{t s} / \sqrt{\boldsymbol{N}}$ \\
$1.0 \mathrm{M}$ & & $1.01 \times 10^{-5}$ & & & \\
$\mathrm{NH}_{3} / \mathrm{NH}_{4} \mathrm{Cl}$ & $1 \times 10^{-5}$ & $1.02 \times 10^{-5}$ & & \\
buffer & & $1.02 \times 10^{-5}$ & $1.02 \times 10^{-5}$ & $2.08 \times 10^{-7}$ & $(1.02 \pm 0.03) \times 10^{-5}$ \\
$(\mathrm{pH}=9.8)$ & & $1.01 \times 10^{-5}$ & & & \\
\hline
\end{tabular}

$\mathrm{N}=4,95 \%$ confidence interval.

\subsection{Determination of Co(III) in a Artificially Prepared Solution Containing $\mathrm{Zn}$ (II) and Fe(III) Using AcOH/AcO- $(\mathrm{pH}=4.0)$ Electrolyte}

Because of the peak overlap of $\mathrm{Zn}(\mathrm{II})$ and $\mathrm{Co}(\mathrm{III})$ in $\mathrm{NH}_{3} / \mathrm{NH}_{4} \mathrm{Cl}$ electrolyte ( $\mathrm{pH}$ = 9.8), the $\mathrm{Co}(\mathrm{III})$ determination can be made in $\mathrm{AcOH}(\mathrm{pH}=4.0)$ electrolyte in the presence of $\mathrm{Zn}(\mathrm{II})$. However as can see from Table 3 although there is no 
interference between $\mathrm{Co}(\mathrm{III})$ and $\mathrm{Zn}(\mathrm{II}), \mathrm{Co}(\mathrm{III})$ peak is broad and $\mathrm{Zn}$ peak is sharp in $\mathrm{AcOH}, \mathrm{pH}=4.0$. To check its accuracy below given artificially prepared solution is prepared and the determination was made.

A sample was prepared containing $\mathrm{Co}(\mathrm{III}), \mathrm{Fe}(\mathrm{III})$ and $\mathrm{Zn}$ (II) each in $1 \times 10^{-3}$ $\mathrm{M}$ (Figure 2), from this $0.1 \mathrm{~mL}$ was taken and added into $10 \mathrm{~mL} \mathrm{AcOH} / \mathrm{AcO}^{-}$ $(\mathrm{pH}=4.0)$ buffer in polarographic cell. A peak for $\mathrm{Zn}(\mathrm{II})$ was observed at -1.02 $\mathrm{V}$ and a peak for $\mathrm{Co}(\mathrm{III})$ at $-1.35 \mathrm{~V}$. As expected there was no peak for $\mathrm{Fe}(\mathrm{III})$, the $\mathrm{Co}$ (IIII) present was determined by additions of standard $1 \times 10^{-5} \mathrm{M} \mathrm{Co}$ (III). The LOD was found as $1 \times 10^{-6} \mathrm{M}$ with $\mathrm{S} / \mathrm{N}=3$. The results are given in Table 5 .

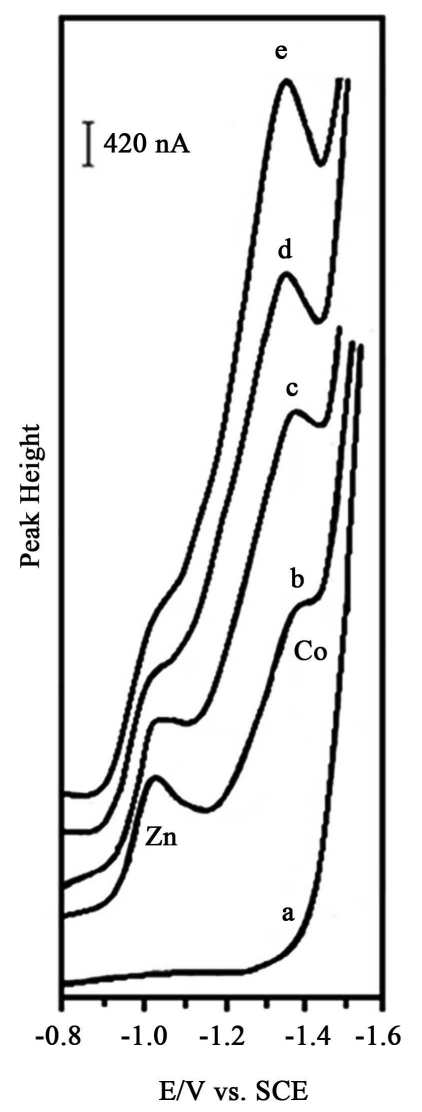

Figure 2. Determination of $\mathrm{Co}(\mathrm{III})$ in a artificially prepared solution containing $1 \times 10^{-3}$ $\mathrm{M}\left(\mathrm{Fe}^{3+}, \mathrm{Co}^{3+}, \mathrm{Zn}^{2+}\right)$ in $1.0 \mathrm{M} \mathrm{AcOH} / \mathrm{AcO}^{-} \mathrm{pH}=4.0$ buffer. a: $10 \mathrm{~mL} 1.0 \mathrm{M} \mathrm{AcOH} / \mathrm{AcO}^{-}$ $\mathrm{pH}=4.0$ buffer; $\mathrm{b}: \mathrm{a}+0.1 \mathrm{~mL}$ artificially prepared solution; $\mathrm{c}: \mathrm{b}+0.1 \mathrm{~mL} 1 \times 10^{-3} \mathrm{M}$ Co(III); d: c + $0.1 \mathrm{~mL} 1 \times 10^{-3} \mathrm{M} \mathrm{Co}(\mathrm{III})$; e: $\mathrm{d}+0.1 \mathrm{~mL} 1 \times 10^{-3} \mathrm{M} \mathrm{Co}(\mathrm{III})$.

Table 5. Determination of $\mathrm{Co}(\mathrm{III})$ in a synthetic sample contaninig $1 \times 10^{-5} \mathrm{M}$ (Fe(III), $\mathrm{Co}(\mathrm{III})$ and $\mathrm{Zn}(\mathrm{II}))$ in $1.0 \mathrm{M} \mathrm{AcOH} / \mathrm{AcO}^{-} \mathrm{pH}=4.0$ buffer.

\begin{tabular}{cccccc}
\hline Medium & $\begin{array}{c}{\left[\mathrm{Co}^{3+}\right](\mathrm{M}) \text { in }} \\
\text { synthetic sample }\end{array}$ & $\begin{array}{c}\text { Determined } \\
{\left[\mathrm{Co}^{3+}\right](\mathrm{M})}\end{array}$ & $\overline{\boldsymbol{x}}$ & $\boldsymbol{s}$ & $\overline{\boldsymbol{x}} \pm \mathbf{t s} / \sqrt{\boldsymbol{N}}$ \\
\hline $1.0 \mathrm{M}$ & & $0.91 \times 10^{-5}$ & & & \\
$\mathrm{AcOH} / \mathrm{AcO}^{-}$ & $1 \times 10^{-5}$ & $0.92 \times 10^{-5}$ & $0.92 \times 10^{-5}$ & $2.75 \times 10^{-7}$ & $(0.92 \pm 0.05) \times 10^{-5}$ \\
buffer & & $0.94 \times 10^{-5}$ & & & \\
$(\mathrm{pH}=4.0)$ & & $0.91 \times 10^{-5}$ & & & \\
\hline
\end{tabular}

$\mathrm{N}=4,95 \%$ confidence interval. 


\subsection{Determination of Vitamin B12 in Injectable Ampoule}

From $1 \mathrm{~mL}$ of B12 sample which was dissolved as given in section "Preparation of reagents" in Sulfuric acid Nitric acid mixture a, sample of $0.1 \mathrm{~mL}$ is taken and added into $10 \mathrm{~mL}$ polarographic cell containing $10 \mathrm{~mL}$ of $\mathrm{NH}_{3} / \mathrm{NH}_{4} \mathrm{Cl}$ buffer $(\mathrm{pH}=9.8)$. A peak at $-1.28 \mathrm{~V}$ for $\mathrm{Co}(\mathrm{III})$ was observed, there was no interfering ion (Figure 3). This peak increased by the additions of standard $0.1 \mathrm{~mL} 1 \times 10^{-3}$ M Co(III). The results obtained for Co(III) in vitamin B12 are given in Table 6, the B12 quantity in the same ampoule was found as $(999 \pm 15) \mu \mathrm{g}$ instead of $1000 \mu \mathrm{g}$ (Table 7).

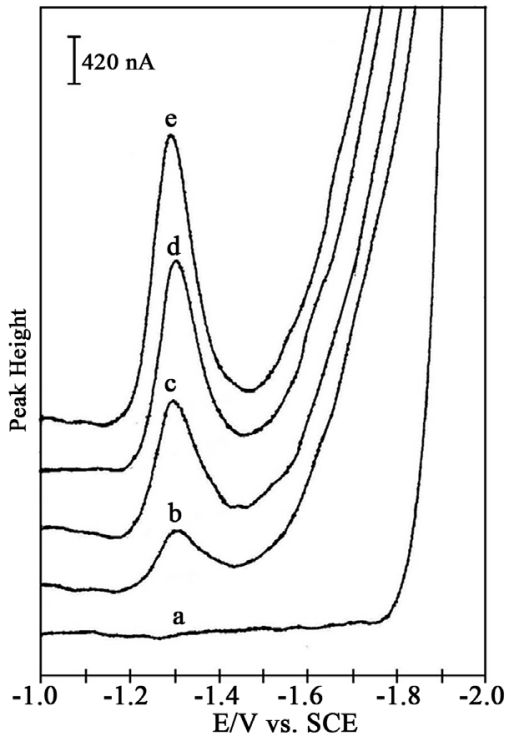

Figure 3. Determination of vitamin $\mathrm{B}_{12}$ in $1.0 \mathrm{M} \mathrm{NH}_{3} / \mathrm{NH}_{4} \mathrm{Cl} \mathrm{pH}=9.8$ buffer. a: $10 \mathrm{~mL}$ $1.0 \mathrm{M} \mathrm{NH}_{3} / \mathrm{NH}_{4} \mathrm{Cl} \mathrm{pH}=9.8$ buffer; b: $\mathrm{a}+0.1 \mathrm{~mL} 1 \times 10^{-3} \mathrm{M} \mathrm{Co}(\mathrm{III}) ; \mathrm{c}: \mathrm{b}+0.1 \mathrm{~mL} 1 \times$ $10^{-3} \mathrm{M} \mathrm{Co}(\mathrm{III}) ; \mathrm{d}$ : c $+0.1 \mathrm{~mL} 1 \times 10^{-3} \mathrm{M} \mathrm{Co}(\mathrm{III}) ; \mathrm{e}: \mathrm{d}+0.1 \mathrm{~mL} 1 \times 10^{-3} \mathrm{M} \mathrm{Co}(\mathrm{III})$.

Table 6. Determination Co(III) in vitamin $\mathrm{B}_{12}$.

\begin{tabular}{cccccc}
\hline Medium & $\begin{array}{c}{\left[\mathrm{Co}^{3+}\right](\mathrm{M}) \text { in }} \\
\text { vitamin } \mathrm{B}_{12}\end{array}$ & $\begin{array}{c}\text { Determined } \\
{\left[\mathrm{Co}^{3+}\right](\mathrm{M})}\end{array}$ & $\overline{\boldsymbol{x}}$ & $\boldsymbol{s}$ & $\overline{\boldsymbol{x}} \pm \boldsymbol{t s} / \sqrt{\boldsymbol{N}}$ \\
\hline $1.0 \mathrm{M}$ & & $7.2 \times 10^{-4}$ & & & \\
$\mathrm{NH}_{3} / \mathrm{NH}_{4} \mathrm{Cl}$ & & $7.5 \times 10^{-4}$ & $7.4 \times 10^{-4}$ & $1.5 \times 10^{-5}$ & $(7.4 \pm 0.2) \times 10^{-4}$ \\
buffer & $7.4 \times 10^{-4}$ & $7.3 \times 10^{-4}$ & & & \\
$(\mathrm{pH}=9.8)$ & & $7.5 \times 10^{-4}$ & & & \\
\hline
\end{tabular}

$\mathrm{N}=4,95 \%$ confidence interval.

Table 7. Determination of $B_{12}$ in vitamin $B_{12}$ ampoule sample $(1000 \mu \mathrm{g})$.

\begin{tabular}{cccccc}
\hline Medium & $\begin{array}{c}\mathbf{B}_{12}(\mu \mathrm{g}) \text { in } \mathrm{B}_{12} \\
\text { ampoule sample }\end{array}$ & $\begin{array}{c}\text { Determined } \\
\mathbf{B}_{12}(\mu \mathrm{g})\end{array}$ & $\overline{\boldsymbol{x}}$ & $\boldsymbol{s}$ & $\overline{\boldsymbol{x}} \pm \boldsymbol{t s} / \sqrt{\boldsymbol{N}}$ \\
\hline $1.0 \mathrm{M}$ & 1000 & 976 & & & \\
$\mathrm{NH}_{3} / \mathrm{NH}_{4} \mathrm{Cl}$ & 1016 & 999 & 24 & $999 \pm 24$ \\
$\operatorname{buffer}(\mathrm{pH}=9.8)$ & 990 & & & \\
\hline
\end{tabular}

$\mathrm{N}=4,95 \%$ confidence interval. 


\section{Conclusion}

In this investigation, a new and highly sensitive DPP method with high reproducibility has been established for the determination of vitamin B12. During the dissolution of vitamin B12 with concentrated acid mixture, the organic structure was decomposed and Co(III) ions could be dissolved in the solution. Thus, it was possible to determine vitamin B12 from the dissolved Co(III). For the polarographic determination of $\mathrm{Co}(\mathrm{III})$ the optimum working conditions had to be studied. It was found that in $1.0 \mathrm{M} \mathrm{NH}_{3} / \mathrm{NH}_{4} \mathrm{Cl}(\mathrm{pH}=9.8)$ buffer $\mathrm{Co}(\mathrm{III})$ and also B12 vitamin can be determined with high reproducibility. In this medium the LOD was $(\mathrm{S} / \mathrm{N}=3) 3.7 \times 10^{-7} \mathrm{M}$. The interference of $\mathrm{Fe}(\mathrm{III}), \mathrm{Zn}(\mathrm{II}), \mathrm{Ni}(\mathrm{II})$, $\mathrm{Cr}(\mathrm{VI}), \mathrm{Cu}(\mathrm{II}), \mathrm{Cd}(\mathrm{II})$ and $\mathrm{Se}(\mathrm{IV})$ ions had also been studied. It was found that only there was a peak overlap with $\mathrm{Zn}(\mathrm{II})$ ion in $1 \mathrm{M} \mathrm{NH}_{3} / \mathrm{NH}_{4} \mathrm{Cl}(\mathrm{pH}=9.8)$ buffer. However, in $1.0 \mathrm{MAcOH} / \mathrm{AcO}^{-}(\mathrm{pH}=4.0)$ buffer there was no peak overlap and the interference could be eliminated. In both media it was possible to determine vitamin B12 with high accuracy.

\section{Acknowledgements}

The authors thank to the Gazi University research fund for the financial support of this research.

\section{Conflicts of Interest}

The authors declare no conflict of interest.

\section{References}

[1] Somer, G. and Çalışkan, A.C. (2009) A New Method for the Simultaneous Determination of $\mathrm{Fe}(\mathrm{III}), \mathrm{Cu}(\mathrm{II}), \mathrm{Pb}(\mathrm{II}), \mathrm{Zn}(\mathrm{II}), \mathrm{Cd}(\mathrm{II})$, and $\mathrm{Ni}(\mathrm{II})$ in Wine Using Differential Pulse Polarography. Journal of Applied Electrochemistry, 39, 2027-2033. https://doi.org/10.1007/s10800-009-9915-1

[2] Somer, G., Kalayci, S. and Sendil, O. (2016) A Nem and Direct Method for the Determinations of Trace Elements in Spinach Using Differential Pulse Polarography. Journal of Electroanalytical Chemistry, 778, 49-52. https://doi.org/10.1016/j.jelechem.2016.07.041

[3] Inam, R. and Somer, G. (1998) An Unusual Polarographic Behavior of Selenite in the Presence of Some Cations. Analytical Sciences, 14, 399-403. https://doi.org/10.2116/analsci.14.399

[4] Taşkoparan, Ü. and Somer, G. (2009) Investigation of Polarographic Interference between Se(IV) and Cr(VI), Its Elimination and Application to Gerede River Water. Journal of Electroanalytical Chemistry, 633, 193-197. https://doi.org/10.1016/j.jelechem.2009.05.013

[5] Somer, G. and Taskoparan, Ü. (2005) Interference between Selenium and Some Trace Elements during Polarographic Studies and Its Elimination. Talanta, 65, 598-602. https://doi.org/10.1016/j.talanta.2004.06.037

[6] Ünal, Ü. and Somer, G. (2011) Simultaneous Determination of Trace Sn(II) and Sn(IV) Using Differential Pulse Polarography and Application. Turkish Journal of Chemistry, 35, 73-85. 
[7] Ünal, Ü. and Somer, G. (2011) A New and Simple Procedure for the Polarographic Speciation and Determination of Trace Inorganic As(III) and As(V) Species. Turkish Journal of Chemistry, 35, 779-792.

[8] Sahbaz, F. and Somer, G. (1992) Determination of Ascorbic Acid in Fruit and Vegetables Using Normal Polarography. Food Chemistry, 44, 141-146.

https://doi.org/10.1016/0308-8146(92)90327-X

[9] Somer, G. and Doğan, M. (2008) Direct and Indirect Methods for the Determination of Vitamin K3 Using Differential Pulse Polarography and Application to Pharmaceuticals. Bioelectrochemistry, 74, 96-100.

https://doi.org/10.1016/j.bioelechem.2008.05.001

[10] Somer, G., Çalışkan, A.C. and Sendil, O. (2014) A New Sensitive Method for the Determination of Trace Mercury by Differential Pulse Polarography: Application to Raw Salt Sample. Journal of Analytical Chemistry, 11, 1083-1088. https://doi.org/10.1134/S1061934814110112

[11] Somer, G., Kalayc1, S. and Almas, Z. (2016) A New, Fast and Sensitive Method for the Determination of Trace Amounts of Nitrite Using Differential Pulse Polarography. Nitric Oxide, 57, 79-84. https://doi.org/10.1016/j.niox.2016.05.001

[12] Moore, M.E., Watters, M., David, A.K., David, M. and Alastair, G. (2015) Vitamin B12 and Cognitive Impairment. In: Martin, C.R. and Preedy, V.R., Eds., Diet and Nutrition in Dementia and Cognitive Decline, Elsevier, London, 637-648. https://doi.org/10.1016/B978-0-12-407824-6.00059-8

[13] Li, H.B., Feng, C. and Yue, J. (2000) Determination of Vitamin B12 in Multivitamin Tablets and Fermentation Medium by High-Performance Liquid Chromatography with Fluorescence Detection. Journal of Chromatography A, 891, 243-247. https://doi.org/10.1016/S0021-9673(00)00724-X

[14] Heudi, O., Kilinc, T., Fontannaz, P. and Marley, E. (2006) Determination of Vitamin B12 in Foodproducts and in Premixes by Reversed-Phase High Performance Liquid Chromatography and Immunoaffinity Extraction. Journal of Chromatography $A, 101,63-68$. https://doi.org/10.1016/j.chroma.2005.09.059

[15] Okba, M. and Sergi, A. (2004) A New Method for the Determination of Vitamin B12 in Seawater. Analytica Chimica Acta, 517, 33-38. https://doi.org/10.1016/j.aca.2004.05.020

[16] Oxspring, D.A., Maxwell, T.J. and Smyth, W.F. (1996) UV-Visible Spectrophotometric, Adsorptive Stripping Voltammetric and Capillary Electrophoretic Study of 2-(5'-bromo-2'-pyridylazo)-5-diethylaminophenol and Its Chelates with Selected Metal Ions: Application to the Determination of Co(III) in Vitamin B12. Analytica Chimica Acta, 323, 97-105. https://doi.org/10.1016/0003-2670(95)00624-9

[17] Yang, N., Wan, Q. and Wang, X. (2005) Voltammetry of Vitamin B12 on a Thin Self-Assembled Monolayer Modified Electrode. Electrochimica Acta, 50, 2175-2180. https://doi.org/10.1016/j.electacta.2004.09.026

[18] Kreft, G.L., De Braga, O.C. and Spinelli, A. (2012) Analytical Electrochemistry of Vitamin B12 on a Bismuth-Film Electrode Surface. Electrochimica Acta, 83, 125-132. https://doi.org/10.1016/j.electacta.2012.07.132

[19] Tomčik, P., Banks, C.E., Trevor, D. and Compton, R.G. (2004) A Self-Catalytic Carbon Paste Electrode for the Detection of Vitamin B12. Analytical Chemistry, 76, 161-165. https://doi.org/10.1021/ac030308j 